\title{
Dissolved organic matter $(C, N, P)$ on the Pernambuco coast and Fernando de Noronha archipelago (Tropical Zone of Western South Atlantic, Brazil) - A contribution to the evaluation of environmental impact
}

\author{
Elisabete de Santis Braga ${ }^{*}$, Glaucia Bueno Benedetti Berbel ${ }^{1}$, Vitor Gonsalez Chiozzini ${ }^{1}$
}

\author{
${ }^{1}$ Laboratory of Biogeochemistry of Nutrients, Micronutrients and Traces in oceans (LABNUT)do Instituto Oceanográfico da \\ Universidade de São Paulo
}

(Praça do Oceanográfico, 191 - Butantã - SP - 05508120 - Brazil)

*Corresponding author: edsbraga@usp.br

\begin{abstract}
The dissolved organic compounds found in seawater offer an indication of biogeochemical processes and anthropogenic influence in the light of their concentrations and behavior associated with different oceanic areas. River inputs contribute with organic loads to seawater according to the level of natural and urban influence. A dilution of this material is expected toward ocean. Around oceanic islands, the quantity of organic matter results from the life cycle of marine organisms and from human occupation. The ratios of dissolved organic carbon (DOC), dissolved organic nitrogen (DON), dissolved organic phosphorus (DOP) and the association with dissolved oxygen can be used to evaluate the environmental conditions in terms of natural and anthropogenic impacts. Available information about the essential dissolved organic compounds $(\mathrm{C}, \mathrm{N}$ and $\mathrm{P})$ in seawater is rare. This study seeks to encourage the use of dissolved organic compounds in environmental impact assessment in coastal areas of Brazil. The spatial distribution of DOC, DON, DOP and urea was analyzed in four regions: Itamaracá (ITA), Recife Inner Shelf (RIS), Fernando de Noronha Island (FN) and Recife Harbor (RH), all in Pernambuco State - Brazil. In the case of DOC, the values obtained varied from $51.60 \mu \mathrm{mol}$ $\mathrm{L}^{-1}\left(0.62 \mathrm{mg} \mathrm{L}^{-1}\right)$ to $358.47 \mu \mathrm{mol} \mathrm{L}^{-1}\left(4.30 \mathrm{mg} \mathrm{L}^{-1}\right)$, DOP values varied from 0.01 to $2.16 \mu \mathrm{mol} \mathrm{L}^{-1}$, both presenting their highest values in RH, the most intensely urbanized area. In relation to DON, an extremely high value $92.89 \mu \mathrm{mol} \mathrm{L}^{-1}$, with urea reaching $12 \mu \mathrm{mol} \mathrm{L}^{-1}$, both in $\mathrm{RH}$, reflects organic and sanitary discharge. Sometimes the urea concentration was associated with precarious sewage treatment combined with tourist activity, as in the case of FN. No significant spatial variation was observed for DOP taking into account all the stations and regions, and the values presented a greater range of variation in FN. The DOC:DON ratios were higher than 7 (2-4 times the Redfield ratio) and revealed the quality of the organic matter and the importance of the local process of remineralization, confirming that the N-limitation enhanced the use of organic forms, mainly on FN. The preserved oligotrophic conditions of the RIS, Itamaracá and FN were observed in relation to dissolved organic compounds $(\mathrm{C}, \mathrm{N}, \mathrm{P})$, but, as regards $\mathrm{FN}$, effective monitoring actions are advisable as it is a pristine area.
\end{abstract}

Descriptors: Dissolved organic nitrogen, dissolved organic phosphorus, total organic carbon, urea, Coastal and oceanic areas.

\section{Resumo}

Os compostos orgânicos dissolvidos encontrados na água do mar oferecem uma indicação de processos biogeoquímicos e influência antropogênica à luz de suas concentrações e comportamentos associados a diferentes áreas oceânicas. Os aportes de rios contribuem com cargas orgânicas para a água do mar de acordo com o nível de influência natural e urbana. Uma diluição deste material é esperada no oceano. Em torno das ilhas oceânicas, a quantidade de matéria orgânica é influenciada pelo ciclo de vida dos organismos marinhos e pela ocupação humana. As proporções de carbono orgânico dissolvido (DOC), nitrogênio orgânico dissolvido (DON), fósforo orgânico dissolvido (DOP) e sua associação com oxigênio dissolvido podem ser utilizadas para avaliar as condições ambientais em termos de impactos naturais e antropogênicos. A informação disponível sobre os compostos orgânicos dissolvidos essenciais $(\mathrm{C}, \mathrm{N}$ e $\mathrm{P})$ na água do mar é rara. Este estudo busca incentivar o uso de compostos orgânicos dissolvidos na avaliação de impacto ambiental nas áreas costeiras do Brasil. A distribuição espacial de DOC, DON, DOP e ureia foi analisada em quatro regiões: Itamaracá (ITA), Plataforma Interna de Recife (RIS), Ilha Fernando de Noronha (FN) e Porto de Recife (RH), todos em Pernambuco Brasil. No caso do DOC, os valores obtidos variaram de 51,60 $\mu \mathrm{mol} \mathrm{L}{ }^{-1}\left(0,62 \mathrm{mg} \mathrm{L}^{-1}\right)$ a $358,47 \mu \mathrm{mol} \mathrm{L}^{-1}\left(4,30 \mathrm{mg} \mathrm{L}^{-1}\right)$, os valores de DOP variaram de 0,01 a 2,16 $\mu \mathrm{m} \mathrm{L}^{-1}$, ambos Apresentando seus valores mais altos em $\mathrm{RH}$, a área mais intensamente urbanizada. Em relação ao DON, um valor extremamente alto de $92,89 \mu \mathrm{mol} \mathrm{L}-1$, com ureia atingindo $12 \mu \mathrm{mol} \mathrm{L}-1$, ambos em RH, refletem a descarga orgânica e de esgoto. Às vezes, a concentração de ureia esteve associada ao tratamento precário de esgoto combinado com a atividade turística, como no caso de FN. Nenhuma variação espacial significativa foi observada para DOP tendo em conta todas as estações e regiões, e os valores apresentaram maior variação de FN. Os índices DOC:DON foram superiores a 7 (2-4 vezes a relação Redfield) e revelaram a qualidade da matéria orgânica e a importância do processo local de remineralização, confirmando que a N-limitação aumentou o uso de formas orgânicas, principalmente em FN. As condições oligotróficas preservadas em RIS, Itamaracá e FN foram observadas em relação aos compostos orgânicos dissolvidos $(\mathrm{C}$, $\mathrm{N}, \mathrm{P}$ ), mas no que diz respeito ao $\mathrm{FN}$, são recomendáveis ações de monitoramento efetivas, pois é uma área remota preservada.

Descritores: Nitrogênio orgânico dissolvido, Fósforo orgânico dissolvido, Carbono orgânico total, ureia, Áreas costeiras e oceânicas. 


\section{INTRODUCTION}

The processes of organic matter construction and degradation in the marine environment are permanent and associated with the predominant metabolism of the system. The dissolved organic $\mathrm{C}, \mathrm{N}$ and $\mathrm{P}$ forms contribute to the understanding of the natural scenarios in each zone of marine systems and also, reveal the degree of anthropogenic influence (Cozzi et al., 2014). On this basis, the comprehension of the organic matter dynamic with a focus on dissolved organic matter expressed by $\mathrm{C}, \mathrm{N}$ and $\mathrm{P}$ was used in four different environments with distinct levels of anthropogenic influence and marine hydrodynamic as a contribution to evaluation of environmental impact.

Since Harvey (1955), it has been assumed that in oceanic areas, low nutrient concentrations during the greater part of the year indicate that primary production is nutrient-limited. On the other hand, it is known that in coastal areas, mainly in zones with riverine inputs, the presence of nutrients increases naturally and that nowadays the anthropogenic contribution promotes an excess of nutrients, indicating an environmental risk of eutrophication even when the initial forms are organic compounds, which are easily mineralized.

There are essentially three sources of organic dissolved material in aquatic environments, the decomposition of plant and animal material with an estimated 15 $-50 \%$ loss of total biomass by post-mortem changes in the permeability of cell membranes and the effects of autolytic enzymes (Krause et al., 1961) such as amino acids, more easily degradable, keto-acids and the most refractory material dependent on bacterial action. A second source of dissolved organic material is the release of extracellular components by living plants and animals by the excretion and secretion of products of their metabolism. A variable rate of from less than $15 \%$ to more than $30 \%$ of total fixed carbon is released as extracellular product by phytoplankton species (Eppley and Sloan, 1965; Watt, 1966; Antia et al., 1963, Parsons and Seki, 1970; Goto et al., 1999). The third source is the anthropogenic contribution in the form of sewage, domestic and agricultural effluents, port activities and others organic effluents. The importance of organic matter in aquatic systems is noteworthy, but not enough data are available from some parts of coastal and oceanic areas, as it is presumed that more and more organic material reaches the oceans. The dissolved fraction of organic matter represents the principal matrix to be worked on by microorganisms releasing inorganic compounds for primary production, which reinforces the need for studies focused on the biogeochemical behavior of organic matter in seawater.

Some studies of the biogeochemistry of dissolved organic carbon (DOC) and dissolved organic nitrogen (DON) in the open oceans have been published (Bates and Hansell, 1999; Hansell, 2002) yet, despite the importance of coastal seas for the cycling of dissolved organic matter (DOM) (Duursma, 1961; Walsh et al., 1988; Wollast, 1991), few studies have focused on these seas (Hung et al., 2003).

Regardless of its refractory character, a relatively large fraction of that DOM is degraded after being mixed with seawater, with turnover times ranging from days to years (Cauwet, 2002). Though time has passed, Bates and Hansell's (1999) observation continues to be valid considering that much remains to be learned about the spatial gradients of organic carbon and nitrogen and the processes that control the fluxes and cycling of carbon in oceanic coastal regions. Seasonal studies are important to enable us to understand the effect of wet and dry periods on DOM cycling. This study therefore seeks to provide more information about DOM (DOC, DON and DOP) on the northeastern Brazilian coast.

\section{DiSSOLVED ORGANIC CARBON (DOC)}

In general, riverine inputs of DOM represent about 0.25 Gt $\mathrm{C}$ per year. This annual input accounts for only about $0.04 \%$ of the DOC content of the oceans, assessed at 685 Gt C (Hansell and Carlson, 1998).

By virtue of the various processes that occur in estuarine water, linked to terrestrial input with large quantities of humic acids and alloctone production of organic matter, the concentration of DOC is higher than in either fresh or sea water. Further, domestic waste contributes an important fraction of organic matter to hydrological systems. In the ocean, as previously suggested by some authors (Duursma, 1961, 1965; Menzel, 1964), the DOC concentration can be used to trace the subsurface movement of water. It is efficient when linked to the vertical flux in view of its homogeneity and low values in deep waters, and when associated with temperature and salinity values in deep water, the behavior of organic matter is quasi-conservative (Menzel, 1970). The DOC concentration undergoes a predictable decrease with distance from the continent and toward the deeper waters. In general, dissolved organic carbon has an indirect relation with the 
levels of bioavailable inorganic compounds and with the excretion and decomposition of particulate organic matter. In particular, microorganisms such as heterotrophic bacteria remove DOC by mineralization and by its incorporation into bacterial cell tissue.

The range of DOC in seawater is between 1500 and $2000 \mathrm{~g} \mathrm{~m}^{-2}$ (Braga, 2002), the carbohydrates constituting the principal class of organic compounds in seawater $(\sim 70 \%)$. A variety of compounds integrate the DOC, including protein and free amino-acids, hydrocarbons $(\sim 1 \%)$, lipids, vitamins and other compounds such as urea, nucleic acids $(<1 \%)$ and a contribution of humic substances $(10-30 \%$ of DOC) is significant in estuarine systems; however, a variety of complex chemical structures belonging to the humic group reach the ocean and the recent introduction of personal care products (such as medicines, beauty products, personal hygiene products, sun block, etc.) form a new group of DOC present close to the coast. Inland waters may introduce anthropogenic DOC in estuaries as a result of pollution, including oil at sea and pesticides in rivers (Aston, 1978). A common process that retains organic compounds near the mouth of estuaries is the flocculation process.

Finally, DOC normally presents a richness of labile compounds more easily biodegradable by microorganisms than particulate matter and whose decomposition is more difficult in the open ocean than in coastal waters near solid surfaces on which heterotrophic microorganisms are abundant (Braga, 2002).

\section{DISSOLVED ORGANIC NITROGEN (DON)}

Nitrogenous organic compounds can be found in the marine environment in particulate and dissolved forms in various chemical speciation (amino acids, proteins, lipid nitrogen, urea, alkaloids and others), with concentrations spatially and temporally distributed in different ways. The decomposition and metabolism of organic $\mathrm{N}$ can lead to the formation of ammonium and urea composing the inorganic and organic dissolved pool of $\mathrm{N}$, as well as other organic compounds.

The availability of nitrogen in the organic form in surface seawater is remarkable because of the metabolism of the system, including the primary production process and the food chain generation of organic matter and organic detritus. The degradation process occurs by means of the oxidation of the organic matter in the euphotic zone, during its sinking and also when it reaches the sediments.
The nitrogen cycle works among the inorganic components, forms derived from organic matter and during their integration into biological processes. Organic nitrogen is a key element in the construction of living organic matter, dissolved inorganic nitrogenous compounds being most commonly used in marine primary production, in the form of $\mathrm{N}$-ammonium, nitrate and nitrite. The assimilation of $\mathrm{N}$-ammonium takes place principally by means of phytoplankton organisms and its regeneration in the marine environment is more complex as it depends on the activity of microorganisms. The main sources of the $\mathrm{N}$-ammonium occurring in the marine environment are the decomposition of organic nitrogen by bacteria; excretion by zooplankton and other animals, including anoxic bacteria; discharge from streams, and precipitation over the sea. The main ammonium sinks include ammonium assimilation by phytoplankton and ammonium oxidation to nitrite and nitrate by nitrification (Wada and Hattori, 1991). The nitrate nitrogen nutrient is the most stable and abundant form of nitrogen in the open ocean and is controlled primarily by assimilation by phytoplankton, regeneration through the decomposition of organic matter and denitrification under anaerobic conditions (Wada and Hattori, 1991). Although nitrate is the most abundant form of nitrogen nutrient found in the ocean, ammonium is the form preferably assimilated by phytoplankton, since this is the ammonium ion, a nitrogen in their optimal oxidation state for its more direct assimilation during the protein forming process. Nitrite is the intermediary in oxidationreduction reactions involving ammonia and nitrate. Nitrite is not found in high concentrations in the natural marine environment, its concentration being governed mainly by biological processes such as oxidative production by nitrifying bacteria; its production and consumption occurring through the respiration of bacteria that use nitrogen compounds as electron acceptors, and oxidative consumption by the nitrifying bacteria.

\section{UREA IN THE NITROGEN CYCLE}

Marine organisms eliminate products resulting from $\mathrm{N}$-metabolism with different characteristics for each one of the invertebrate and vertebrate marine groups. Many marine organisms excrete various nitrogen products simultaneously, as is the case of some fish which eliminate ammonium, urea and creatine in different proportions (Braga, 2002). The presence of urea, despite not being the main product of the nitrogen excretion of many groups of 
organisms, is considered to be connected to two metabolic groups: the cycle of ornithine-urea on one hand and purine-urea, another part of the nitrogen cycle, on the other (Braga, 2002). Urea is the predominant final metabolite that permits the excretion of nitrogen from mammals with concentrations of $7.7 \mathrm{~g} \mathrm{l}^{-1}$ in human urine (Udert et al., 2006). The increase in concentrations of urea in coastal areas is attributed to urban sewage, the contribution of atmospheric deposition being rare (Cozzi et al., 2014). In the marine environment, urea is an important component of the biogeochemical nitrogen cycle (Antia et al., 1991; Bronk, 2002; Solomon et al., 2010). Rather low levels of urea are found in the open sea $\left(0.3 \mu \mathrm{mol} \mathrm{L}^{-1} \mathrm{~N}\right)$, whereas higher values (reaching $13 \mu \mathrm{mol} \mathrm{L}^{-1} \mathrm{~N}$ ) are often observed in the coastal and estuarine zones.

On the other hand, urea is also considered an organic source of $\mathrm{N}$ for small groups of organisms in seawater. A preference for the assimilation of urea by the Phaeodactylum, a phytoplankton organism, has been observed (McCarthy, 1972). So, in the biogeochemical nitrogen cycle, urea plays a role in the excretion of metabolic products of $\mathrm{N}$, it is also a source of dissolved organic nitrogen for some autotrophic species and a substrate for bacteria to have the potential to indicate marine pollution on the coast.

\section{DisSOLVED ORGANIC PHOSPHORUS (DOP)}

Phosphorus is an essential nutrient for primary production and can be a limiting factor in marine systems (Benson et al., 1996) due to its role in the construction of organic matter and also by reason of its participation in the conversion of energy throughout the biological system by means of ATP molecules. In natural waters, dissolved phosphorus is found in several chemical forms that may be categorized as inorganic (protonated forms of $\mathrm{PO}_{4}^{3-}$ ) or organic (incorporated into organic molecules, such as those of biological origin including nucleic acids, polyphosphates, phosphorus esters and phosphonates) (Thomson-Bulldis and Karl, 1998; Benitez-Nelson, 2000; Kolowith et al., 2001). It has always been generally accepted that all plankton can utilize inorganic phosphorus, only in the last 15 years, however, have oceanographers demonstrated that dissolved organic phosphorus (DOP) is available to both phytoplankton and bacteria for production (Monaghan and Ruttenberg, 1999; Kolowith et al., 2001). It is, therefore, important to quantify organic phosphorus as it is potentially available for primary production in coastal systems.
The availability of phosphorus to the marine environment is considered to be one of the main controlling factors of primary production on both ancient and modern geological time scales (Schenau et al., 2005). Phosphorus is provided for estuarine, coastal and ocean environments through the processes of rock weathering and river transport.

Another form of dissolved phosphorus in the aquatic environment is its organic form whose sources are adenosine triphosphate (ATP), phosphonucleotides, phospholipids and many products of the decomposition of the organic matter of phosphate diesters and monoesters and phosphonates (Kolowith et al., 2001). The main sources of the phosphorus that supports marine primary production are inorganic, but there are several species that have the capacity to take advantage of both $\mathrm{N}$ and $\mathrm{P}$ in the form of small organic molecules (Ruttenberg, 2005). In situations where a $\mathrm{P}$ deficiency occurs, the activity of the alkaline phosphatase enzyme may be activated in order to hydrolyze the phosphoric esters to support primary production (Kobayashi et al., 1983). Yet phosphorus is considered one of the main constraints on primary production along with nitrogen.

Phosphorus is part of the group of nutrients essential for life and has a biogeochemical cycle. It participates notably in marine pollution mainly in the eutrophication process due to the input from domestic and industrial effluents and leaching in agricultural and port regions; P's behavior thus deserves attention in coastal systems under different degrees of anthropic impact.

\section{STUDY AREAS}

This study was undertaken in four different areas of the Northeastern region of Brazil, namely, Fernando de Noronha Island (FN), Recife Inner Shelf (RIS), Recife Harbor (RH) and Itamaracá (ITA), all of them in the state of Pernambuco.

Fernando de Noronha Archipelago is located $345 \mathrm{~km}$ off the northeastern coast of Brazil, at $03 \circ 51 \mathrm{~S} ; 32 \circ 25 \mathrm{~W}$, and consists of one large island and 19 small adjacent islets, covering a total area of $26 \mathrm{~km}^{2}$. About $70 \%$ of the main island and the coast from the shore out to the $50 \mathrm{~m}$ isobath constitute a marine protected area (MPA), established in 1988. A large section, including the remaining portion of the main island, out to the $50 \mathrm{~m}$ isobath, is an Environmental Protected Area (EPA) designated for sustainable use where fishing and boat traffic are allowed. The climate is tropical with an average air temperature of 
$25.4{ }^{\circ} \mathrm{C}$, mean water temperature of $26-27{ }^{\circ} \mathrm{C}$ and mean salinity of 36 (Maida and Ferreira, 1997). In this region 8 stations (N1-N8) located in the Inner Sea (off the northwestern coast of the island) were sampled (Fig. 1).

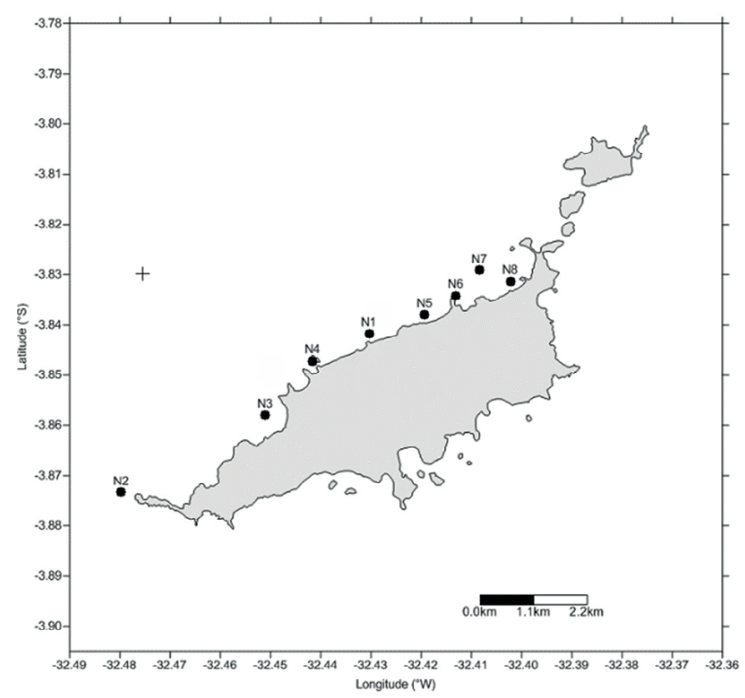

Figure 1. Spatial distribution of sampling stations (FN) on Fernando de Noronha Island, in March 2015.

Recife city was built in the estuarine area of the Capibaribe River and several smaller rivers (Beberibe, Tejipio, Jordão and Jiquia), with a network of secondary waterways. The tide, penetrating the estuary, favors mangrove ecosystems, threatened by urban planning. Recife has a hot and humid tropical monsoon climate. Temperatures have little seasonal variation, with a mean of $25^{\circ} \mathrm{C}$. Under the influence of the Southern Oscillation (El Nino in 2005 and 2010, La Nina in 2000) and the Atlantic Dipole (Intertropical Convergence Zone), the average rainfall is $2000 \mathrm{~mm} /$ year. There are two clearly distinguishable seasons: a rainy one (March-August, $250 \mathrm{~mm} / \mathrm{month}$ ), and a dry one (September-February, $100 \mathrm{~mm} / \mathrm{month})$. Rainfall is also spatially highly irregular, decreasing westwards from the city. The years 1998-1999 and 2012-2013 are considered to have been extremely dry, and are known as Recife's most severe droughts. The average levels of precipitation for 20122013 attained $1770 \mathrm{~mm}, 11 \%$ below the mean for the period 1961-1990. Except for May 2013, each month of 2012-2013 was between 15 and 90\% drier than the respective monthly averages for 1961-1990. Nine stations (R1-R9) were sampled on the neighboring shelf and 4 in the port channel (R10-R13), (Fig. 2).

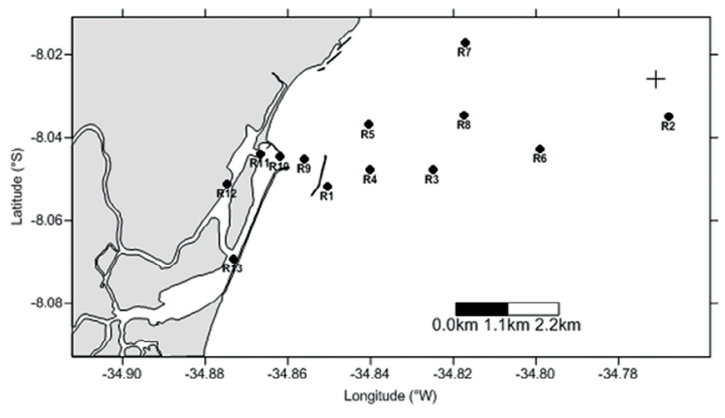

Figure 2. Spatial distribution of stations on Recife's inner shelf (RIS) and in the Recife Harbor (RH) channel, March 2015.

The coastal estuarine complex of the Ilha de Itamaracá, located on the northern coast of the state of Pernambuco, approximately $50 \mathrm{~km}$ from the city of Recife, is a region distinct from the others by virtue of its high primary productivity and faunal diversity (CONAMA, 2001). The flat tidal area where the sampling was conducted is about $300 \mathrm{~m}$ from the waterline during the average low water spring tides. The area close to the coast is covered by very shallow waters, which makes it difficult to work on with a medium-sized vessel. Six stations (I1-I6) were sampled in this region (Fig. 3).

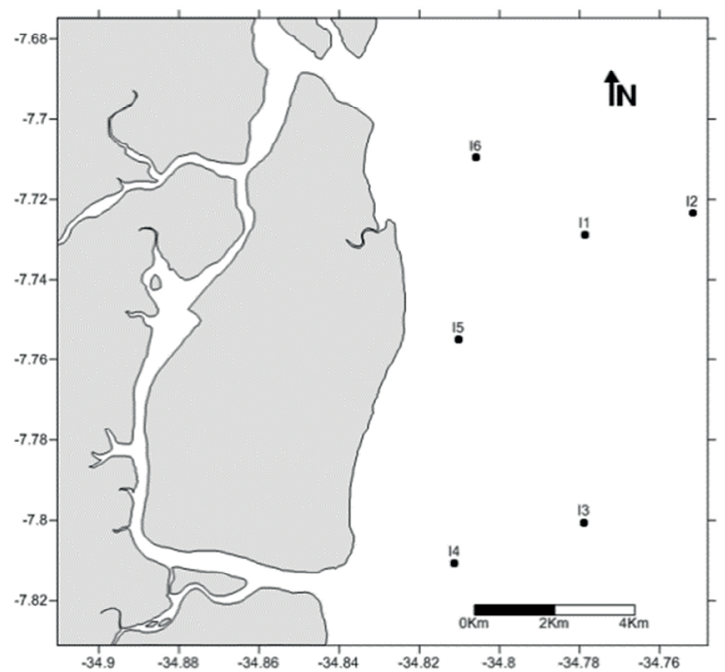

Figure 3. Spatial distribution of stations (I) off Itamaracá (ITA), in March 2015.

\section{MATERIAL AND METHODS}

\section{SAMPLING}

Sampling was undertaken in March, 2015, in the dry season on Fernando de Noronha (FN) Island, Recife's Inner Shelf (RIS), in Recife Harbor (RH) and at Itamaracá (ITA). 
The seawater samples were collected using Hydrobios ${ }^{\circledR}$ bottles for determining dissolved oxygen, salinity and $\mathrm{N}$-ammonium and to measure temperature and turbidity. A van Dorn sampling bottle was used for taking water for the dissolved organic $(\mathrm{C}, \mathrm{N}$ and $\mathrm{P})$ determinations and also to determine inorganic nitrogen (nitrite and nitrate) and phosphorus (phosphate). The water samples were filtered using a preheated $\left(450{ }^{\circ} \mathrm{C}\right.$ for $\left.4 \mathrm{~h}\right)$ Whatman ${ }^{\circledR} \mathrm{GF} / \mathrm{F}$ filter (47 mm), except for $\mathrm{N}$-ammonium. DON and DOP were sub-sampled from filtered material and analyzed initially as total dissolved nitrogen and phosphorus. In relation to DOC, the subsamples were not filtered and were acidified with a minimum of $\mathrm{H}_{3} \mathrm{PO}_{4}$ concentrate in order to eliminate the carbonates (DIC).

\section{Abiotic MEASUREMENTS}

Temperatures were measured with protected reversal mercury thermometers with a precision of $\pm 0.02^{\circ} \mathrm{C}$. Salinity was determined with a Beckman RS-10 induction salinometer with a precision of 0.001 . Turbidity was measured with a nephelometer Hach ${ }^{\circledR}$ model 2100P with 0-100 NTU. The $\mathrm{pH}$ was measured using a pHmeter Orion ${ }^{\circledR}$ with a precision of \pm 0.001 . Dissolved oxygen was measured by the Winkler method as described in Grasshoff et al. (1983), using a Titrando Metrohm ${ }^{\circledR}$ system, with a precision of $0.02 \mathrm{~mL} \mathrm{~L}^{-1}$. The oxygen saturation (OS) was calculated based on an equation given by Aminot and Chaussepied (1983). Ammonium was measured as described by Tréguer and Le Corre (1975). Nitrate and nitrite were determined by a colorimetric method as described in Grasshoff et al. (1983) using an Autoanalyzer II, Bran-Luebbe ${ }^{\circledR}$ with a precision of $0.01 \mu \mathrm{mol} \mathrm{L} \mathrm{L}^{-1}$ for both. Dissolved inorganic phosphorus (phosphate) was measured as described in Grasshoff et al. (1983) by the molybdenium blue spectrophotometric method, with a precision of $0.01 \mu \mathrm{mol} \mathrm{L}^{-1}$. The dissolved inorganic nutrients described here, were used to compose the DIN and DIP used to obtain DON and DOP values from total dissolved nitrogen (TDN) and phosphorus (TDP) analyses resulting from the photo-oxidation process described below.

\section{ANALYSES OF DISSOLVED ORGANIC COMPOUNDS}

\section{DISSOLVED ORGANIC CARBON (DOC)}

DOC was determined by a high-temperature catalytic oxidation method using a Vario Cube ${ }^{\circledR}$ analyzer. Briefly, acidified seawater samples were purged with pure synthetic air for $5 \mathrm{~min}$ to eliminate inorganic carbon, and then, 7
$\mathrm{mL}$ was injected directly into the vertical furnace which contained a standard platinum catalyst at a temperature of $850^{\circ} \mathrm{C}$. Oxidation of the DOC occurs by non-dispersive infrared detection of the carbon dioxide generated. Only the instrument blank was considered as the DOC blank in the calculation of DOC concentrations. During the experiments, the instrument blank was about 3-6 mmol L-1.

DISSOLVED ORGANIC NITROGEN (DON) AND DISSOLVED ORGANIC PHOSPHORUS (DOP)

Dissolved Organic Nitrogen (DON) and Dissolved Organic Phosphorus (DOP) were analyzed by UVoxidation process in presence of an excess of dissolved oxygen assured by adding hydrogen peroxide, thus determining Total Dissolved Nitrogen (TDN) and Total Dissolved Phosphorus (TDP) (Armstrong et al., 1966, Braga, 2002). The extract after photo-oxidation was analyzed for the nitrate and phosphate as described before. Dissolved nitrogenous compounds in seawater were oxidized to nitrate in the presence of dissolved oxygen under the action of UV radiation energy.

\section{UREA}

The urea content was assessed using the analytical method described by Aminot and Kerouel (1982) adapted for manual determination. The samples were placed in reaction flasks and received $1 \mathrm{~mL}$ of two reagents (A - diacetyl monoxide and thiosemicarbazide; and $\mathrm{B}$ - sulphuric acid and iron chloride) after which, the flasks were submerged in the water bath $\left(90^{\circ} \mathrm{C}\right)$ for 45 minutes. Then, the samples were cooled until reach the laboratory temperature to proceed with the spectrophotometer reading at $526 \mathrm{mn}$. The method has a detection limit of $\pm 0.02 \mu \mathrm{mol}$ $\mathrm{L}^{-1}$ of urea.

\section{DATA TREATMENT}

The Shapiro -Wink test was used to test the normality of the data for analyzing the type of correlation to be used (Spearman or Pearson), spatial variation being determined by the analysis of variance (ANOVA). The spatial distribution of the studied parameters were showed by figures made using Microsoft Excel 2013 ${ }^{\circledR}$ software, which also undertook Spearman's nonparametric correlation (rs). The Principal component analysis (PCA) was made on the basis of standardized data of the variables studied, and was undertaken using Past 3.0 software ${ }^{\circledR}$. The data were treated with a significance level $\alpha=0.05$ to ascertain whether there were spatial differences. 


\section{RESULTS}

Physical ANd Chemical Characteristics of THE WATER

Values of temperature, salinity, dissolved oxygen (DO), saturation of oxygen (DO), $\mathrm{pH}$ and turbidity are summarized in Table 1. According to the Shapiro -Wink test, all of them were considered non-parametric and the Kruskall-Wallis test was used for comparing spatial differences between Itamaracá, RIS, RH and FN.

Temperature, considering all the areas sampled, varied from 28.03 to $31.10^{\circ} \mathrm{C}$ (Table 1), and the highest average was observed at Itamaracá, a coastal region with shallow, salt water that presented the highest salinity value (36.97) and, the $\mathrm{pH}$ and the maximum turbidity indicating the influence of estuarine dynamic, not evidenced by the salinity.

According to Figure 4, salinity values remained above 35 for Itamaracá and FN, whereas on RIS, values of salinity started at 30 and presented varying temperature. On the other hand, values in the harbor channel $(\mathrm{RH})$ presented a seaward increase in salinity $\left(r^{2}=0.86\right)$ with a more restricted variation of temperature. The oxygen values were low at RH, indicating that the consumption process exceeded the production and input of gas. A similar situation was observed, specifically at I6, a shallow station, the northernmost sampled point, with a minimum of $2.08 \mathrm{~mL}$ $\mathrm{L}^{-1}$, increasing towards the northern exit of the Santa Cruz Channel.

Evaluating the dissolved oxygen represented as percentage of saturation, a remarkable tendency, similar to that for DO concentrations, was observed. The low $\mathrm{pH}$ values and highest turbidity indicated an association between these two regions, ITA and $\mathrm{RH}$, both under greater terrestrial influence, due to the Capibaribe river, an area with the highest values for turbidity (Table 1). Dissolved oxygen saturation varied, in general, from 23 to $130 \%$ considering all the regions and the lowest dissolved oxygen and saturation values were found in the regions close to the continent. Supersaturation in DO was observed on RIS, but especially on FN, the highest values were found in oceanic waters.

Observing the physical and chemical parameters, the continuity of the properties of the harbor channel on Recife's inner shelf was evident, and a river plume was identified. The values from less impacted waters, increasing towards the open sea, were observed as also at ITA, while at $\mathrm{FN}$, the values presented characteristics of pristine regions, almost continuously. These conditions will be referred to shortly.

Mitigation OF SURFACE WATER PROPERTIES FROM RECIFE HARBOR (RH) TO RECIFE'S INTERNAL SHELF (RIS)

\section{HYDROLOGICAL AND CHEMICAL PROPERTIES}

Figure 5 shows the spatial distribution of physical and chemical parameters in the surface waters of RIS and in the adjoining RH. Surface water temperatures were higher in shallow marine waters, especially at station R1 (Fig. 5a). As expected, salinity values indicated both fresh and brackish waters in $\mathrm{RH}$ due to the influence of the Capibaribe river and, the values increasing seawards (Fig. 5b). Dissolved oxygen presented extremely low values along $\mathrm{RH}$, from 1.21 to $1.94 \mathrm{~mL} \mathrm{~L}^{-1}$ (Fig. 5c), indicating some cases of hypoxia and the percentages of dissolved oxygen saturation being between 23 and 51\%. Low dissolved oxygen saturations were located at stations R12 and R13, where turbidity presented high values, 54.8 and 70 NTU, respectively (Fig. 5d). High Suspended Particulate Matter (SPM) content were found in $\mathrm{RH}$,

Table 1. Physical and Chemical data of temperature, salinity, dissolved oxygen (DO), percentage of dissolved oxygen (\% $\mathrm{DO}), \mathrm{pH}$ and turbidity (range, average (A) and SD).

\begin{tabular}{|c|c|c|c|c|c|c|c|}
\hline & & $\begin{array}{l}\text { Temp. } \\
(\mathrm{oC})\end{array}$ & Salinity & $\begin{array}{c}\text { DO } \\
(\mathrm{mL} \mathrm{L-1)}\end{array}$ & $\%$ Sat. DO & $\mathrm{pH}$ & $\begin{array}{c}\text { Turbidity } \\
\text { NTU }\end{array}$ \\
\hline ITA & $\begin{array}{c}\text { Range } \\
\mathrm{A} \pm \mathrm{SD}\end{array}$ & $\begin{array}{c}28.65-31.10 \\
(29.66 \pm 0.90)\end{array}$ & $\begin{array}{c}35.20-36.97 \\
(36.66 \pm 0.57)\end{array}$ & $\begin{array}{l}(2.08-5.48) \\
(4.57 \pm 0.82)\end{array}$ & $\begin{array}{c}48-110 \\
(97 \pm 32)\end{array}$ & $\begin{array}{c}7.00-8.51 \\
(8.12 \pm 2.70)\end{array}$ & $\begin{array}{c}0.38-6.45 \\
(2.62 \pm 1.89)\end{array}$ \\
\hline RIS & $\begin{array}{l}\text { Range } \\
\mathrm{A} \pm \mathrm{SD}\end{array}$ & $\begin{array}{c}28.10-30.14 \\
(28.70 \pm 0.58)\end{array}$ & $\begin{array}{c}30.55-36.50 \\
(35.17 \pm 1.83)\end{array}$ & $\begin{array}{c}4.53-6.05 \\
(4.97 \pm 0.42)\end{array}$ & $\begin{array}{l}101-113 \\
(107 \pm 4)\end{array}$ & $\begin{array}{c}8.06-8.22 \\
(8.17 \pm 0.04)\end{array}$ & $\begin{array}{c}0.32-3.64 \\
(1.34 \pm 0.97)\end{array}$ \\
\hline RH & $\begin{array}{l}\text { Range } \\
\mathrm{A} \pm \mathrm{SD}\end{array}$ & $\begin{array}{c}28.03-28.93 \\
(28.42 \pm 0.35)\end{array}$ & $\begin{array}{c}2.95-35.96 \\
(17.56 \pm 12.98)\end{array}$ & $\begin{array}{c}1.21-3.57 \\
(2.09 \pm 0.89)\end{array}$ & $\begin{array}{c}23-81 \\
(44 \pm 22)\end{array}$ & $\begin{array}{c}7.08-8.07 \\
7.58 \pm 0.38\end{array}$ & $\begin{array}{c}7.43-73.40 \\
28.60 \pm 25.99\end{array}$ \\
\hline FN & $\begin{array}{l}\text { Range } \\
\mathrm{A} \pm \mathrm{SD}\end{array}$ & $\begin{array}{c}28.30-30.00 \\
(29.08 \pm 0.40)\end{array}$ & $\begin{array}{l}36.19-36.30 \\
(36.25 \pm 0.03)\end{array}$ & $\begin{array}{c}5.09-5.95 \\
(5.40 \pm 0.24)\end{array}$ & $\begin{array}{l}115-130 \\
(123 \pm 6)\end{array}$ & $\begin{array}{c}7.56-8.56 \\
(8.24 \pm 0.23)\end{array}$ & $\mathrm{Nd}$ \\
\hline
\end{tabular}

nd $=$ not determined I = Itamaracá RIS = Recife's Inner Shelf RH = Recife Harbor FN = Fernando de Noronha 


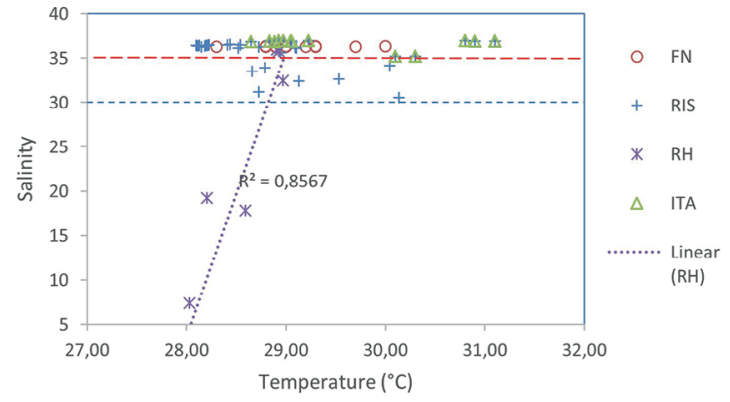

Figure 4. Salinity versus temperature in 4 areas: Fernando de Noronha (FN), Recife's Inner Shelf (RIS), and Recife Harbor (RH), Itamaracá (ITA), in March 2015. Red and blue broken lines show the salinity range between 30 and 35 .

decreasing towards the RIS (Fig. 5e). Particulate organic matter (POM) presented a high values at station R1, in seawater close to the continent and under the influence of the southern current (Fig. 5f).

\section{DISSOLVED ORGANIC COMPOUNDS}

High concentrations of Dissolved Organic Carbon (DOC), Dissolved Organic Nitrogen (DON) (Fig. 6 a, b) and urea were found at stations 4,5 and 9 , while the highest values of DON were found at the surface in the RIS area. These high concentrations may be attributed to Capibaribe river runoff. This river presents high anthropogenic impact because it receive input of sewage only primarily treated, that contributing to enhance of dissolved organic compound concentrations on the RIS. On the other hand, the external stations on the RIS presented DOC, DON and urea values similar to those of the open ocean (Table 2). Percentages of DON in TDN were 8 to $96 \%$ with low values at R1. The highest values of urea were found at the surface at station 5. Despite presenting high values, the percentages of urea in DON were about $33 \%$ and the highest values of these percentages were found at station RIS 1 , with $71 \%$ of urea in DON pool. DON and DOP spatial concentrations in the surface waters of RH and RIS presented different patterns. High levels of DON were found southern of RH, whereas high levels of DOP were found in the northern part of RH (Fig. 6c). DOC presented high concentrations in all the sectors of RH, in the direction to R4 station. As happened with the DON tendency, high concentrations of urea were found in the southern part of RH (Fig. 6d). Considered as an impacted region, RH presented low values of dissolved oxygen, as well as low values of percentages of saturation, while high values of DOC, DON, NTD and urea were observed, mainly in low salinity waters, influenced by river inputs, associated with high anthropogenic influence.
DOC, DON AND DOP IN AREAS WITH LOWEST ANTHROPOGENIC INFLUENCE - ITAMARACÁ AND FERNANDO DE NORONHA ISLAND (IN PRISTINE AREAS)

Observing the Itamaracá region, located northern of Recife, the coastal data enables us to divide it into two areas: $i$ ) stations 1 to 3 , more distant from the island, presented waters with low values of turbidity, DOC, urea and DON, and ii) stations 4 to 6 , closest to the coast, that presented shallow waters with high levels of turbidity and urea. The lowest salinity was found at station 6 , at the northern exit of the Santa Cruz channel.

The organic nitrogen (DON) pool in terms of TDN showed percentages that varied from 45 to $97 \%$. The lowest value was observed at station ITA 4, probably resulting from a different terrestrial input and biological contribution resulting from the secretion and excretion of organic compounds. In relation to excretion, the percentages of urea in the DON varied from 2 to $56 \%$, with higher values located at the coastal stations, from ITA 4 to 6 , submitted to greater anthropogenic influence in an area of modest human occupation as compared to that of $\mathrm{RH}$.

In relation to the oceanic island of Fernando de Noronha, stations FN 5 and 6 presented high DON concentrations, reaching $4.31 \mathrm{mmol} \mathrm{L}^{-1}$ in the bottom water at station 5 (Conceição beach). The highest value of DOC was found at the bottom at station 6 (Cachorro beach). Percentages of urea in the DON varied from 12 to $63 \%$, in this case, the highest percentage being found at FN 2 .

No relationship was found between salinity and DOC, DOP, DON or urea, indicating the possibility of rapid changes in concentrations of these parameters, mainly at Itamaracá and FN (Fig. 7a-d). On the other hand, a significant relationship between DOC and salinity (Fig. 7a) was found in the RH region indicating a process of dilution. DON and salinity also presented a close relationship on the RIS (Fig. 7b).

\section{DISCUSSION}

\section{RELATIONSHIP BETWEEN DISSOLVED ORGANIC COMPONENTS IN SURFACE WATERS OF RIS AND RH}

On the RIS, although R13 presented high concentrations of urea, at this point, the percentage of urea in relation to DON was $18 \%$, whereas at R1 and R12, it accounted for $70 \%$ and $56 \%$, respectively. Additionally, the significant correlation $(r>0.70)$ between dissolved organic matter 

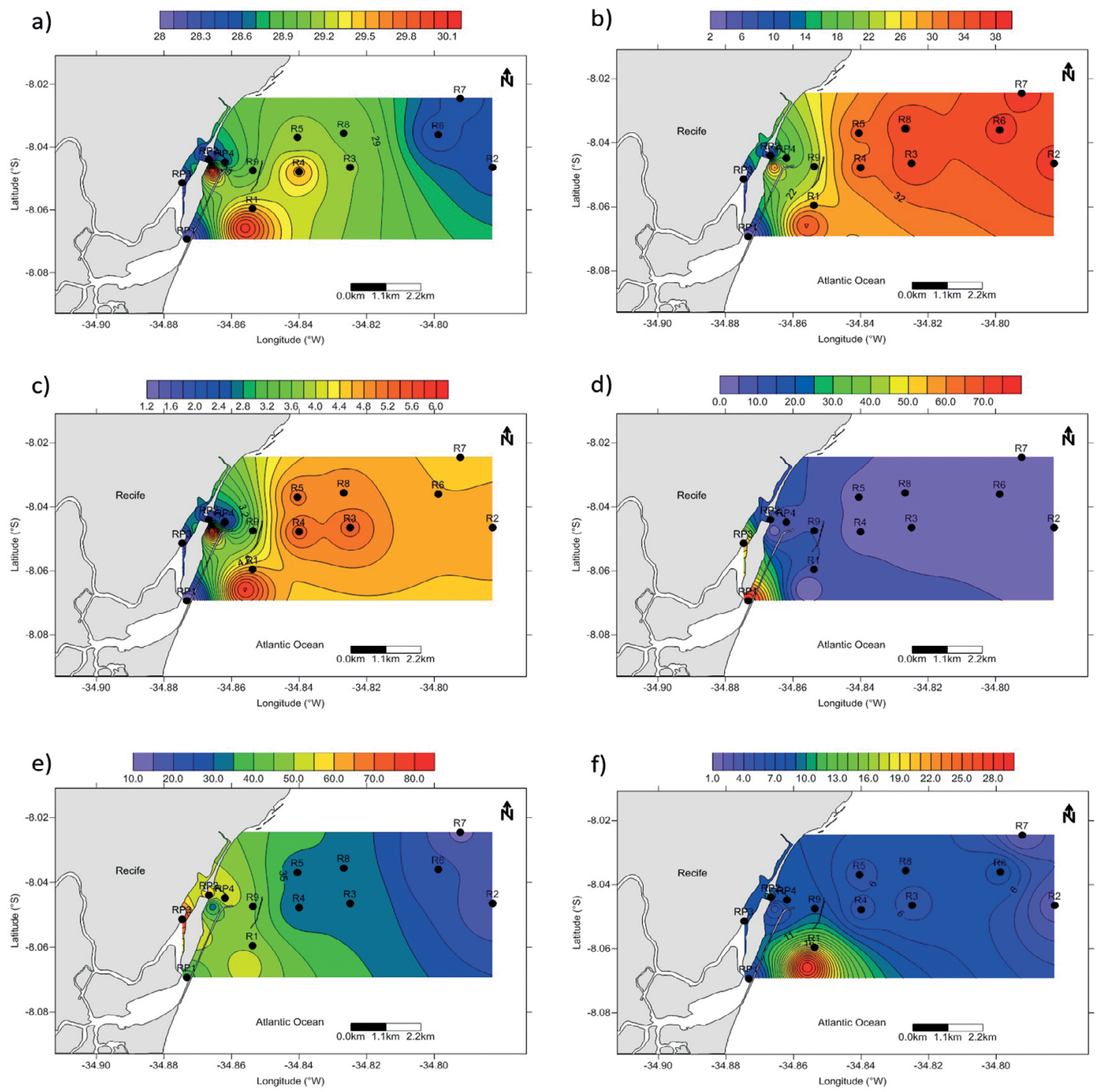

Figure 5. Spatial distribution of hydrological and chemical properties: (a) Temperature $\left({ }^{\circ} \mathrm{C}\right)$, (b) Salinity, (c) Dissolved oxygen $\left(\mathrm{mL} \mathrm{L}^{-1}\right),(\mathrm{d})$ Turbidity (NTU), (e) Suspended Particulate Matter $\left(\mathrm{mg} \mathrm{L}^{-1}\right)$ and (f) Particulate organic matter ( $\mathrm{mg} \mathrm{L}^{-1}$ ) in surface waters of RIS and RH, PernambucoBrazil, in March 2015.

(DOC, DON, DOP and urea) and turbidity was clearly remarkable (Tab. 3) and, in function of it, is possible to infer that these high correlations are related to anthropogenic influence in the Capibaribe river due to untreated sewage inputs. Commonly, in the water body that receive a untreated sewage, the values of urea and dissolved organic matter could reach high concentrations and also the percentage of urea can representing an important fraction of organic matter, informing that it is an important $\mathrm{N}$-source in relation to inorganic N pool, as noticed by Cozzi et al. (2014). It was also observed that DON was related to the highly turbid waters at station R13 and in general, the high SPM values were related to fresh water, as shown in figure 8 and as observed in the PCA results.

\section{Molar RATIOS BETWEen DISSOLVED ORGANIC COMPOUNDS}

In general, the highest values of the DOC:DON molar ratio were found on FN and a wide range of values was observed, varying from 19 to 234 , on the other hand, lowest values were 
a)

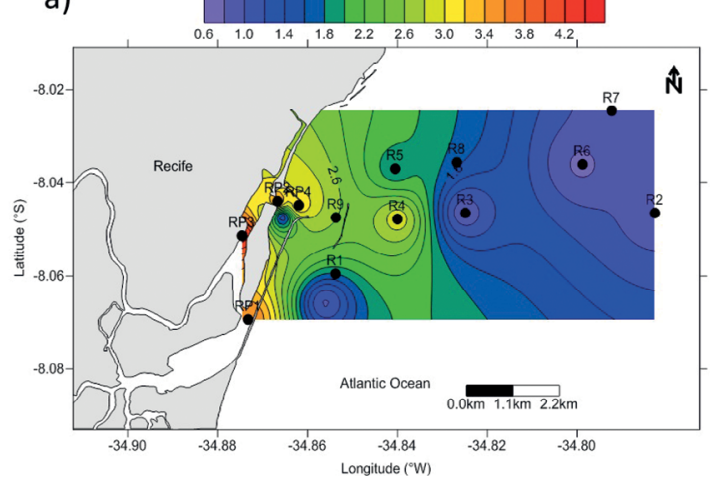

c)

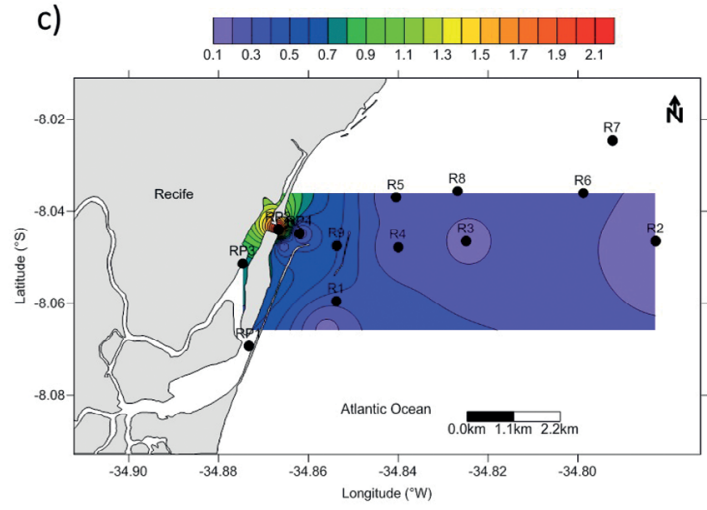

b)

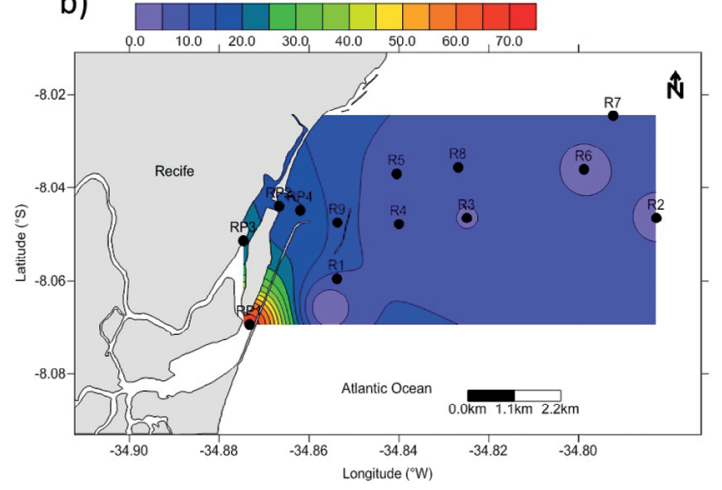

d)

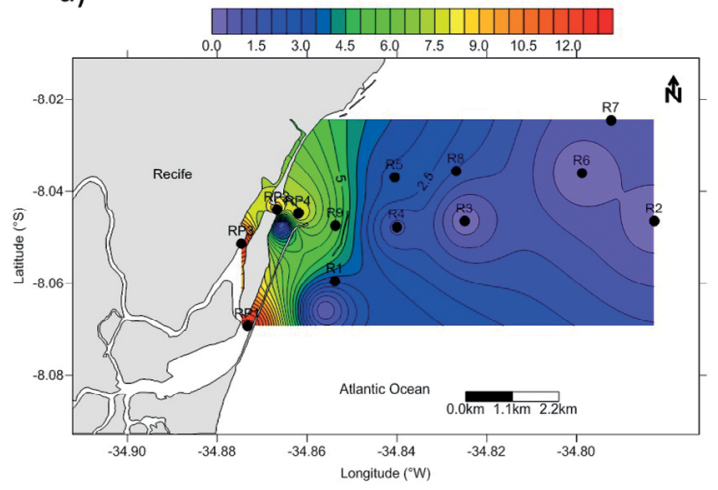

Figure 6. Spatial distribution of dissolved organic matter: (a) Dissolved Organic Carbon - DOC (mg L $\left.{ }^{-1}\right)$, (b) Dissolved Organic Nitrogen - NOD $\left(\mu \mathrm{mol} \mathrm{L}{ }^{-1}\right),(c)$ Dissolved Organic Phosphorus $\left(\mu \mathrm{mol} \mathrm{L}^{-1}\right)$, (d) Urea $\left(\mu \mathrm{mol} \mathrm{L}^{-1}\right)$, Pernambuco-Brazil, in March 2015.

found at Itamaracá. The highest values could be due to terrestrial inputs and/or to degradation processes in shallow waters with a terrestrial contribution associated with the quality of the organic matter rich in $\mathrm{C}$ compounds. In the case of Fernando de Noronha (FN), an essentially basaltic oceanic island, the terrestrial input is rare due to the very low rainfall, conducing to infer that degradation processes associated with high temperatures may be are predominant in its waters.

Generally, if DOC:DON values closer to 6.6 had been observed, that would have indicated a major contribution of organic matter from plankton, fecal pellets and other compounds of biological origin, easily degradable and with great nutritive value, however in all the regions studied, the values of DOC:DON were higher than 7. In this study, most of the stations presented average values of DOC:DON about 2 to 4 times greater than the Redfield ratio. Kolowith et al. (2001), in Pacific Ocean observed values of $\mathrm{C}: \mathrm{N}: \mathrm{P}$ higher than Redfield ratios when considering dissolved organic forms.

This may indicates that in FN there is a probable contribution of DOM, mainly from the local water processes than from any terrestrial contribution, adding to it the low rainfall, typical of the dry season (March 2015), reflecting in a different availability of DON in relation to COD. This is maybe due to the quality of the organic matter, as also due to the time residence of DON in this $\mathrm{N}$-limited environment.

The DOC:DON ratio generally ranges from 15 to 30 in the open sea (Haikalla et al. 2015), but in all the regions studied, the DOC:DON molar ratio exceeded the Redfield ratio as observed by Kolowith (2001). Further, there was no significant linear relationship between DON and DOC in any of the regions, indicating the strong uncoupling of $\mathrm{N}$ and $\mathrm{C}$ in the DOM pool (Fig. 9 a), evidencing different origin and/or, biogeochemical processes on $\mathrm{C}$ and $\mathrm{N}$.

Areas with continental link, as RIS and RH, a high DOC:DON ratio may be related to humic substances presence and its terrestrial origin result in mostly more aromatic compounds and in consequence, it have higher DOC:DON ratios than those from marine source, which are more aliphatic compounds (Stuermer at al., 1978, Hansell and Carlson, 2015). 


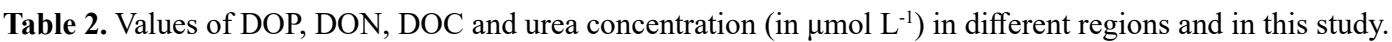

\begin{tabular}{|c|c|c|c|c|c|}
\hline & $\begin{array}{c}\text { DOP } \\
(\mu \mathrm{mol} \mathrm{L}-1)\end{array}$ & $\begin{array}{c}\mathrm{DON} \\
(\mu \mathrm{mol} \mathrm{L}-1)\end{array}$ & $\begin{array}{c}\text { DOC } \\
\left.(\mu \mathrm{mol} \mathrm{L})^{-1}\right)\end{array}$ & $\begin{array}{c}\text { Urea } \\
\left(\mu \mathrm{mol} \mathrm{L}{ }^{-1}\right)\end{array}$ & $\begin{array}{c}\text { Urea } \\
\left.(\mu \mathrm{mol} \mathrm{L})^{-1}\right)\end{array}$ \\
\hline Bay of La Jolla & - & - & - & $0.54-1.00$ & McCarthy et al., 1972 \\
\hline Alaska coast & - & - & - & $0.25-2.20$ & DeManche, 1973 \\
\hline $\begin{array}{l}\text { Ubatuba São Paulo- } \\
\text {-Brazil }\end{array}$ & - & - & - & $0.05-1.71$ & Braga, 1995 \\
\hline Santos Bay & $\begin{array}{c}0.11-0.76 \text { (winter) } \\
0.00-3.24 \text { (summer) }\end{array}$ & $\begin{array}{l}2.57-20.39 \\
1.49-25.07\end{array}$ & - & $\begin{array}{l}0.70-4.02 \\
0.40-3.60\end{array}$ & Saraiva, 2002 \\
\hline Mississipi Plume & $0.00-2.50$ & - & - & - & Rinker \& Powell (2002) \\
\hline $\begin{array}{l}\text { Cape Fear River (USA) } \\
\text { Estuary }\end{array}$ & $0.57-1.77$ & $14.80-37.79$ & - & - & Dafner et al. (2007) \\
\hline Santos Channel & $\begin{array}{c}0.00-2.08 \text { (summer) } \\
0.20-0.50 \text { (winter) }\end{array}$ & - & - & - & Berbel (2008) \\
\hline São Vicente Channel & $\begin{array}{c}1.0 .50 \text { (summer) } \\
0.01-1.02 \text { (winter) }\end{array}$ & - & - & - & Berbel (2008) \\
\hline Plym Estuary (USA) & - & $10-80$ & $90-180$ & - & Badr et al. (2008) \\
\hline Gulf of Cadiz & - & $0-20$ & $42-198$ & - & Ribas-Ribas et al. (2011) \\
\hline $\begin{array}{l}\text { Gulf of Trieste } \\
\text { (Italy) }\end{array}$ & - & - & - & $1.2-20.0$ & Cozzi et al. (2014) \\
\hline Gulf of Riga (Baltic Sea) & - & - & $400-570$ & - & Hoikkala et al. (2015) \\
\hline Gulf of Finland & $0.06-0.29$ & $20.4-22.8$ & $483-690$ & - & Hoikkala et al. (2015) \\
\hline Itamaracá & $0.10-0.22$ & $3.30-17.64$ & $50.88-136.81$ & $0.02-056$ & This study \\
\hline RIS & $0.00-0.32$ & $0.94-17.91$ & $40.10-241.88$ & $0.00-2.93$ & This study \\
\hline RH & $0.02-2.16$ & $2.77-92.89$ & $67.22-358.47$ & $0.99-12.71$ & This study \\
\hline $\mathrm{FN}$ & $0.01-0.27$ & $0.39-4.31$ & $58.22-198.53$ & $0.50-4.25$ & This study \\
\hline
\end{tabular}
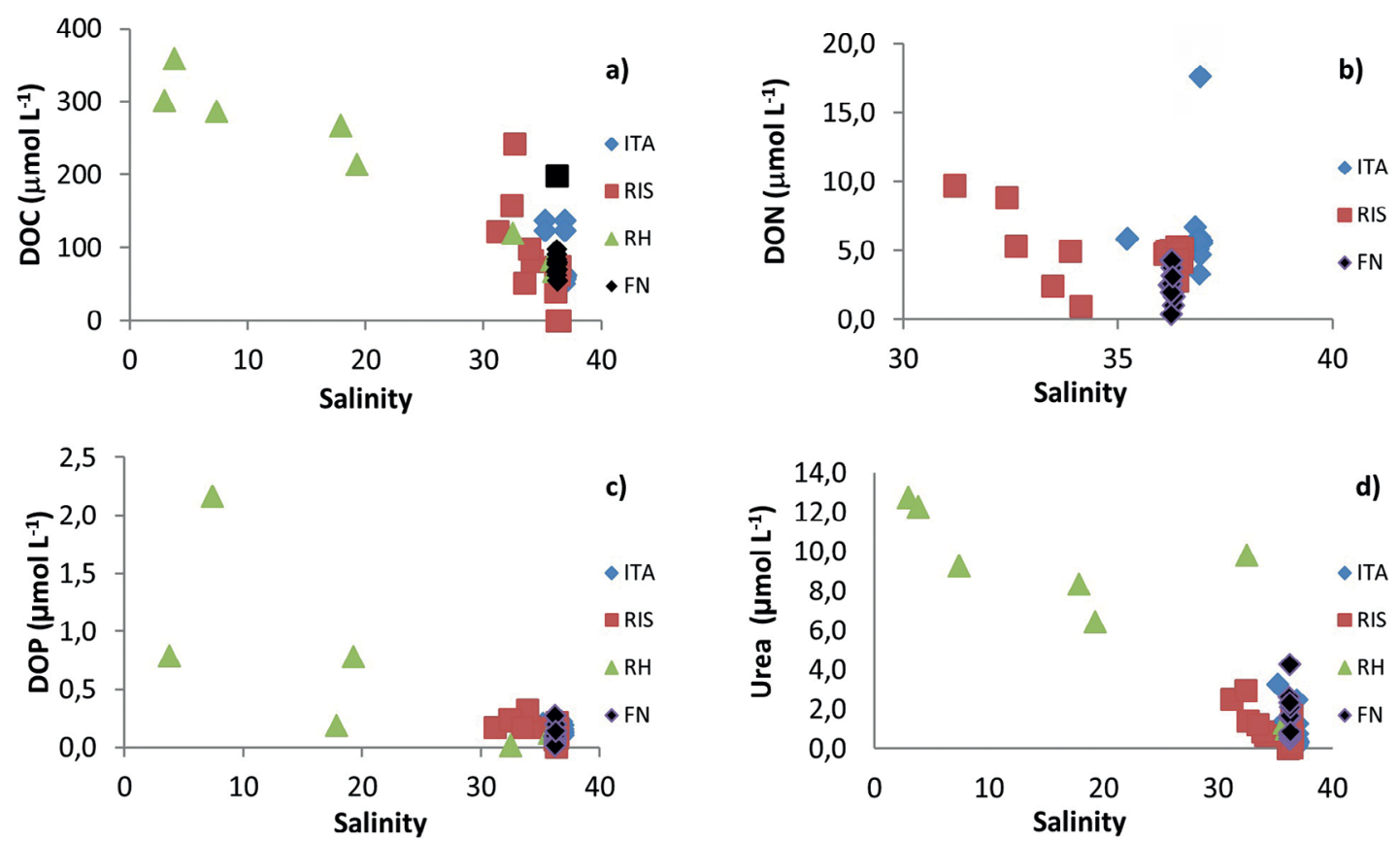

Figure 7. Relationship between salinity and (a) DOC, (b) DON, (c) DOP, and (d) urea on Fernando de Noronha Island, March 2015. 
Table 3. Spearman correlation between DOC, DON and DOP and physical and chemical variables.

\begin{tabular}{|c|c|c|c|c|c|c|c|c|c|c|c|}
\hline & Temp. & Sal. & DO & Turb. & DOC & DON & DOP & Urea & SPM & POM & $\% \mathrm{POM}$ \\
\hline Temperature & 1.00 & & & & & & & & & & \\
\hline Salin. (UPS) & 0.57 & 1.00 & & & & & & & & & \\
\hline $\mathrm{OD}(\mathrm{mL} / \mathrm{L})$ & 0.80 & 0.92 & 1.00 & & & & & & & & \\
\hline Turb. (ntu) & -0.54 & -0.94 & -0.83 & 1.00 & & & & & & & \\
\hline $\mathrm{DOC}$ & -0.42 & -0.91 & -0.82 & 0.77 & 1.00 & & & & & & \\
\hline DON & -0.42 & -0.83 & -0.76 & 0.89 & 0.65 & 1.00 & & & & & \\
\hline DOP & -0.52 & -0.74 & -0.66 & 0.97 & 0.56 & 0.83 & 1.00 & & & & \\
\hline Urea & -0.59 & -0.99 & -0.94 & 0.91 & 0.92 & 0.83 & 0.63 & 1.00 & & & \\
\hline SPM & -0.14 & -0.75 & -0.61 & 0.52 & 0.74 & 0.27 & 0.53 & 0.73 & 1.00 & & \\
\hline POM & 0.41 & -0.02 & 0.11 & -0.05 & -0.05 & -0.16 & 0.02 & -0.01 & 0.48 & 1.00 & \\
\hline$\% \mathrm{POM}$ & 0.45 & 0.38 & 0.42 & -0.31 & -0.46 & -0.33 & -0.24 & -0.41 & 0.00 & 0.84 & 1.00 \\
\hline
\end{tabular}

\section{Surface waters-RIS and RH}

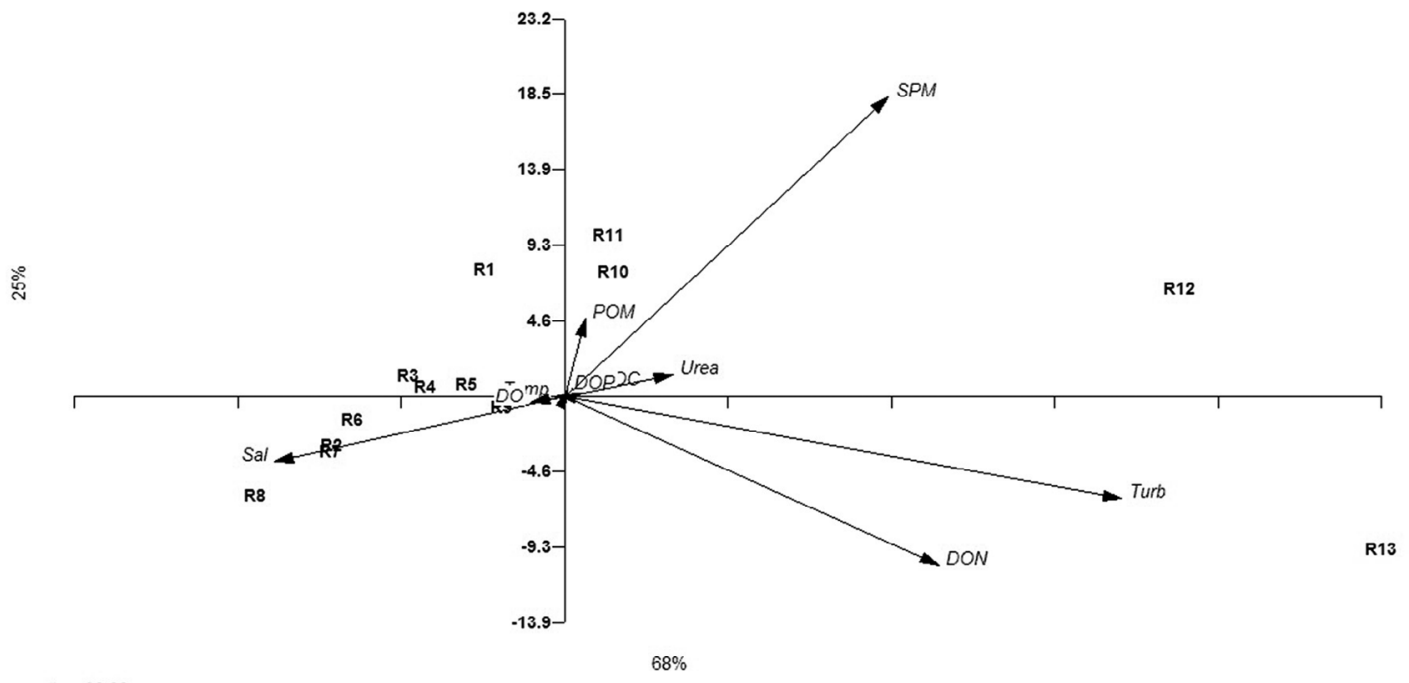

Vector scalinq: 22.92

Figure 8. PCA of surface waters on the Recife inner shelf (RIS) and Recife harbor (RH) in Pernambuco, obtained in March 2015.

Certainly, DOC and DON availability can influences the phytoplankton community organization as noticed by Church et al. (2002) in Pacific Ocean, related to the organic matter cycling.

No relationship between DOC and DOP was found (Fig. 9b) nor between DOP and DON (Fig. 9c). The variability of the ratios is an indication that DOP and DON are not affected by the same processes. DOP has been found to be preferentially mineralized when compared to DON and DOC (Clark et al., 1998; Kolowith et al., 2001), resulting in the nitrogen-enriched ratios as observed for all the stations. DOP is therefore more labile to phytoplankton than
DON in these systems, leading to shorter turnover times in coastal regions (Suzumura et al., 1998).

One explanation for this fact could be that nitrogenrich compounds (amino acids, proteins, etc.) are recycled faster than carbon-rich compounds (mono- and polysaccharides, lipids, etc.) in surface - and warmer - ocean waters (Sambrotto et al., 1993). Therefore, the C:N ratios of DOM are usually more than double the average of C:N ratios of the products of synthesis and early degradation of marine phytoplankton. This finding means that, in this area, the nitrogen component of algal DOM has been utilized. The lowest concentration of dissolved inorganic 

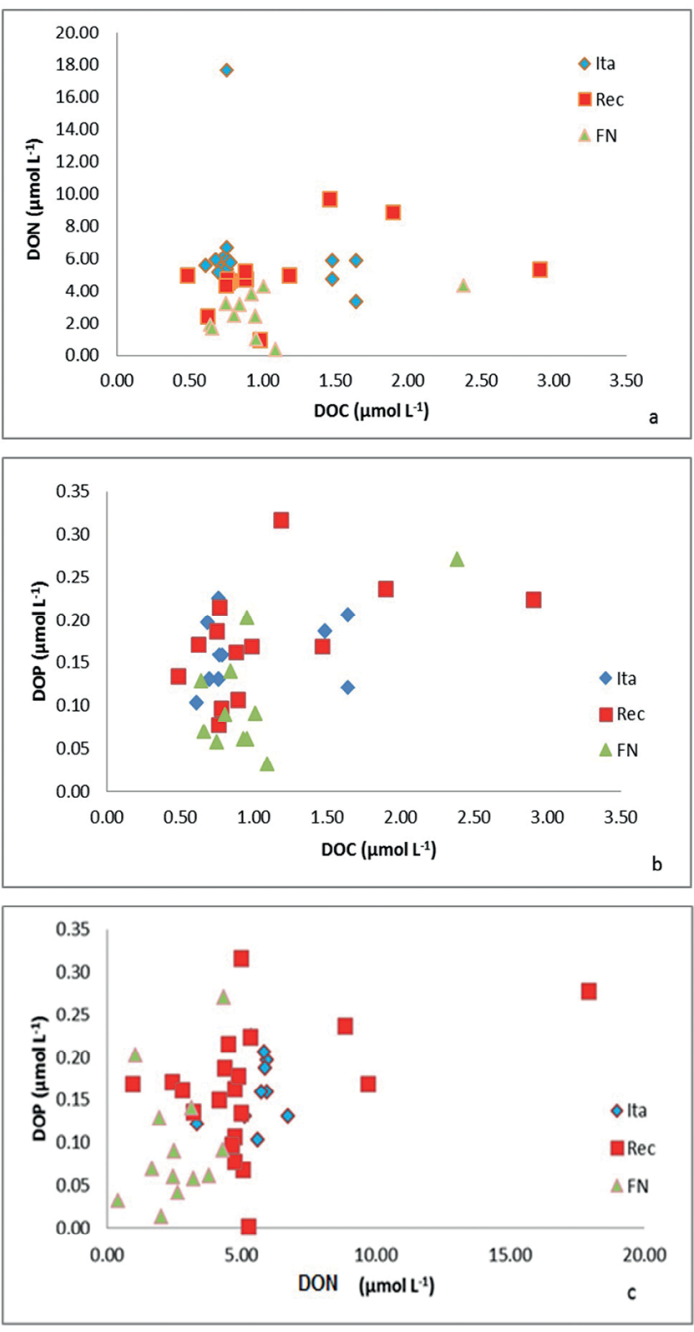

Figure 9. Relationship between (a) DOC:DON (b) DOC: DOP (c) DOP:DON at Ita, REC and FN in March 2015.

nitrogen (Braga et al., in this volume) are found at all the sites typical of oligotrophic waters.

The molar ratio between dissolved oxygen, nitrate and phosphate in marine phytoplankton and in deep oceanic waters is almost constant $\left(\mathrm{O}_{2}: \mathrm{N}: \mathrm{P}=138: 16: 1\right.$; Redfield et al., 1963). Dafner et al. (2007) founding values of $\mathrm{O}_{2}: \mathrm{DON}$ close to the Redfield ratios. That same author reported that on the shelf, the $\mathrm{O}_{2}$ :DON ratios ranged from 24 - 49 and at Itamaracá, RIS and FN, the ratios were extremely high, varying from 16 to 640 , indicating a deficit of organic nitrogen. On the other hand, in $\mathrm{RH}$, values of $\mathrm{O}_{2}$ :DON were extremely low.

\section{ORGANIC COMPOUNDS (DON, DOC AND DOP)} THROUGHOUT THE COASTAL AREA

No differences in concentrations of DOC were found on RIS, FN or Itamaracá, except for RH (ANOVA $p<$ 0.05), (Fig. 10a). On the other hand, DON presented spatial differences among the more pristine areas (FN, RIS and Itamaracá) shown in Figure 10b. No differences among DOP concentrations were observed between stations, including impacted stations such as RH (Fig. 10c).

DOP presented less than $50 \%$ of TDP in RH and curiously also on FN. On the other hand, the highest percentages of DOP/TDP were observed at Itamaracá stations (1 to 5).

According to Dafner et al. (2007), the predominance of DON and DOP in shelf waters could demonstrate either an accumulation of these compounds as the result of terrestrial input from the rivers or of phytoplankton exudation. In this study, there is no river contribution in Itamaracá, as evidenced by salinity of water, however, the suspended particulate matter and the existence of an important calcareous algae bank in this region might account for the principal predominance of DOP and DON, that may be attributed to algae exudation and a terrestrial contribution as is also mentioned by the author quoted and/or to organic matter decomposition and excretion.

Urea also presented maximum values of $4.25 \mu \mathrm{mol} \mathrm{L}^{-1}$ in bottom water off FN (Fig. 10d), maybe in function of the sewage spills. However, as expected, RH presented extremely high concentrations such as $12.72 \mu \mathrm{mol} \mathrm{L}^{-1}$. Cozzi et al. (2014) estimated a background urea concentrations in the Gulf of Trieste of $1.2 \mu \mathrm{mol} \mathrm{L}^{-1}$, a similar finding to the average urea concentrations in the Laje de Santos Marine State Park, around $1.0 \mu \mathrm{mol} \mathrm{L}^{-1}$ (Braga et al., 2017), and low values was also detected in the Ubatuba region, around a pristine island, reaching a maximum of $1.71 \mu \mathrm{mol} \mathrm{L}^{-1}(\mathrm{Braga}, 1995)$. While, Braga (2002) presented a maximum value of 4.02 in winter in Santos Bay, a polluted area, near the source of a human contribution via a submarine sewage outfall, and remarked on the importance of these urea data in a possible monitoring program. Shilova et al. (2017) evidenced the importance of the urea besides nitrate and $\mathrm{N}$-ammonium, as a source of $\mathrm{N}$ influencing the phytoplankton and microbial community composition in the oligotrophic waters of the North Pacific Ocean and remarking that the changes in $\mathrm{N}$ supply would likely favor specific populations of phytoplankton in different oceanic regions and thus, affect both biogeochemical cycles and ecological processes. 
a)

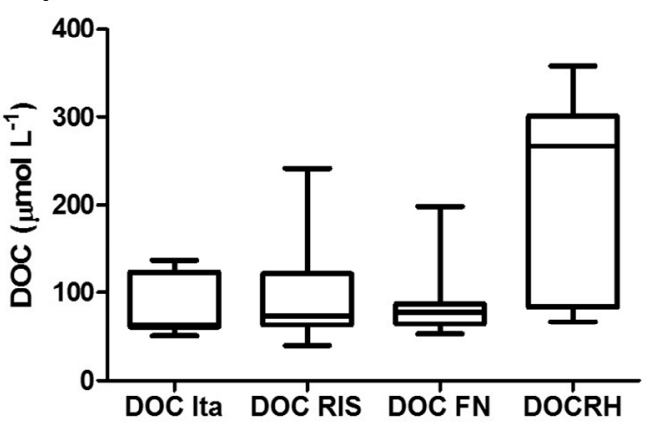

c)

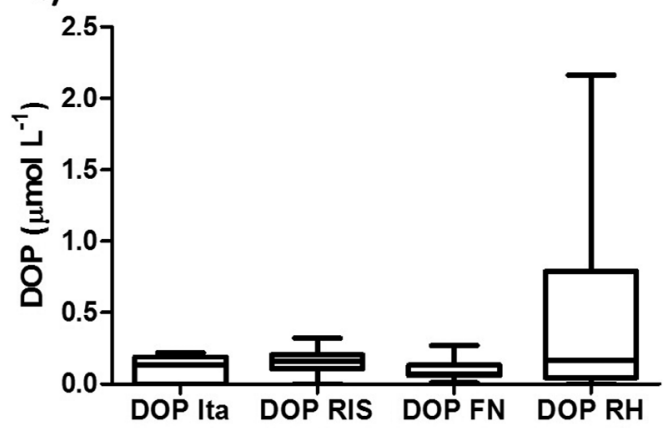

b)

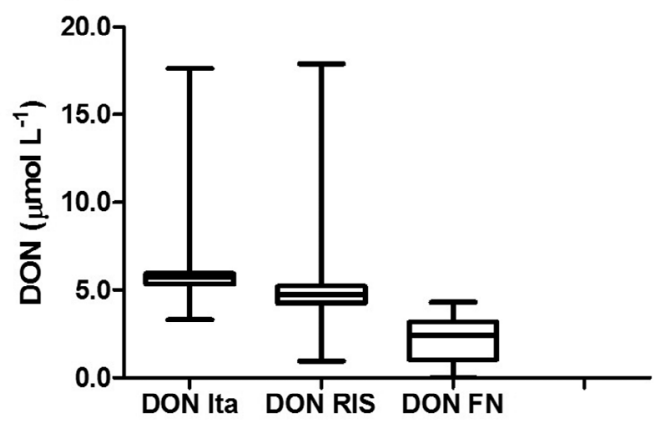

d)

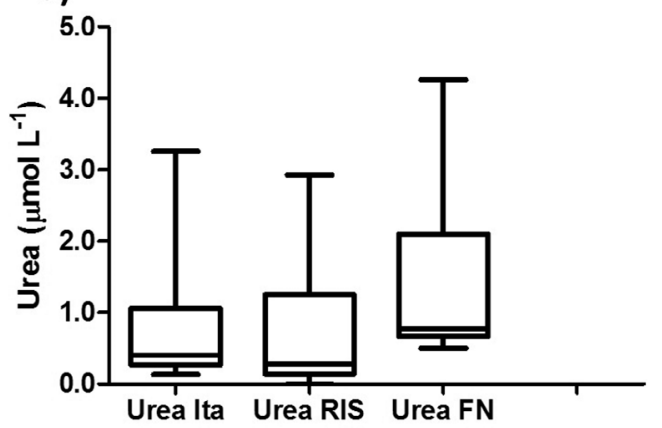

Figure 10. Box Plots of (a) DOC, (b) DON, (c) DOP, (d) DON and Urea, for RH were impossible due to insufficient data for the box plots.

These results demonstrate that the percentage of urea in relation to total dissolved nitrogen and DON is high, even for regions further from the continent and subject to a vigorous hydrodynamic such as that found off $\mathrm{FN}$ and on RIS. On the other hand, Itamaracá (stations 1 to 3) presented percentages of urea of less than $10 \%$ and we can thus infer that $90 \%$ of total dissolved nitrogen indicates the presence of proteins and amino acids from both marine and terrestrial sources of the main form of organic nitrogen. The comparison between Itamaracá, RH, RIS and FN and other coastal stations is important to establish baseline values of dissolved organic compounds mainly for DON, DOC and urea pools.

In relation to the remarkable presence of organisms found on FN and the oligotrophic properties of the oceanic waters in this region, the role of the organic compounds, mainly of $\mathrm{N}$, is sufficiently accounted for the pool of the recycled organic material. Nitrogenous nutrients, such as ammonium, are recycled readily by microheterotrophs, such as bacteria and protozoa and represent a substantial source of $\mathrm{N}$ for phytoplankton organisms (Harrison, 1978;
Caperon et al., 1979; Glibert, 1982). Still, organic compounds could be used directly as a source of nitrogen by some genera of microorganisms.

Link between $\mathrm{N}$ and $\mathrm{P}$ assimilation in oceanic waters is based on the fact that $\mathrm{P}$ has its main source in terrestrial inputs derived principally from riverine sources and in the oceanic area, the atmosphere is a proximal source of $\mathrm{N}$ $\left(\mathrm{N}_{2}\right)$ for primary production (Broecker, 1974).

In certain region, the DOM is a terrestrial signature (Fichot and Benner, 2014), mainly if the rivers input is evident as the case of RH and RIS. The removal of DOM from suspension by flocculation is thus of fundamental importance for the understanding the dynamics and bioavailability of terrestrial-derived DOM and is a key processes in the continuum between the terrestrial system and the benthic environment in estuaries and coastal waters (Fleming-Lehtinen et al., 2015).

In the case of FN, the importance of allochthonous organic matter to coastal food webs is, however, linked to, e.g., nutrient status and the consequent production of autochthonous organic matter, thus varying between systems as observed also by Markager et al. (2011). 


\section{CONCLUSION}

We studied the spatial variations of DOC, DON, DOP and urea in the coastal region and $o \quad n$ the adjacent shelf (Itamaracá, RIS, RH and FN) and demonstrated that in the marine region, concentrations of dissolved organic compounds were typical of shelves and regions with a low impact of anthropogenic pollution at Itamaracá, FN and RIS. These data are important to enable public policies to establish baseline values of dissolved organic compounds in this region, thus contributing to actions directed to preservation.

\section{ACKNOWLEDGEMENTS}

The authors wish to thank the Research Support Foundation of the State of São Paulo (FAPESP 2011/50582-0) and the Foundation for the promotion of Science and Technology of Pernambuco (FACEPE/ APQ0074-1.08/11) as a part of CARECOS Project FAPESP/ FACEPE/ANR for their financial support. We would also like to thank Chiara M. Vieira and Beatriz F. Scigliano for their collaboration with the organic phosphorus analyses and sampling.

\section{REFERENCES}

AMINOT, A. \& KEROUEL, R. 1982. Dosage automatique de l'urée dans l'eau de mer: une méthode très sensible à la diacétylmonoxime. Canadian Journal of Fisheries and Aquatic Sciences, 39, 174-183.

AMINOT, A. \& CHAUSSEPIED, M. 1983. Manuel des Analyses Chimiques en Milieu Marin. $1^{e r}$ ed, Brest, Centre national pour l'exploitation des océans.

ANTIA, N. J., MCALLISTER, C. D., PARSONS, T. R., STEPHEN, K. \& STRICKLAND, J. D. H. 1963. Turther measurements of primary production using a large-volume plastic sphere. Limnology and Oceanography, 8, 166-183.

ANTIA, N.J. HARRISON, P.J. OLIVEIRA L. 1991. The role of dissolved organic nitrogen in phytoplankton nutrition, cell biology and ecology. Phycologia, 30, 1-89.

ARMSTRONG, F. A., WILLIAMS, P. M. \& STRICKLAND, J. D. H. 1966. Photo-xidation of organic matter in sea water by ultra-violet radiation, anlytical and application. Nature, 211: 481-463.

ASTON, S. R. 1978. Estuarine Chemistry. In: RILEY, J. P., CHESTER, R. (ed.) Chemical Oceanography. $2^{\text {nd }}$ ed. v. 7. London: Academic Press.

BADR, E. A, TAPPIN, A. D. \& ACHTERBERG, E. P. 2008. Distributions and seasonal variability of dissolved organic nitrogen in two estuaries in SW England. Marine Chemistry, 110, 153-164. 2008.
BATES, N. R. \& HANSELL, D. A. 1999. A high resolution study of surface layer hydrographic and biogeochemical properties between Chesapeake Bay and Bermuda. Marine Chemistry, 67, 1-16.

BENITEZ-NELSON, C. R. 2000. The biogeochemical cycling of phosphorus in marine systems. Earth-Science Reviews, 51, 109-135.

BENSON, R. L., MCKELVIE, I. D., HART, B. T., TROUNG, Y. B. \& HAMILTON, I. C. 1996. Determination of total phosphorus in waters and wastewaters by on-line UV/thermal induced digestion and flow injection analysis. Analytica Chimica Acta, 326, 29-39.

BRAGA, E. S. 1995. Distribuição sazonal da uréia na região de Ubatuba $45^{\circ} 04 \mathrm{~W}$ e $23^{\circ} 04 \mathrm{~S}$. (Publição especial). Boletim do Instituto Paulista de Oceanografia, 11, 91-98.

BRAGA, E. S. 2002. Bioquímica Marinha - Efeitos de poluição nos processos bioquímicos. $2^{\mathrm{a}}$ ed. São Paulo: FUNDESPA.

BRAGA, E. S.; BERBEL, G. B. B.; CHIOZZINI, V. G. and ANDRADE, N. C. G. 2017 Dissolved organic nutrients (C, N, P) in seawater on the continental shelf in the Southwestern South Atlantic with emphasis State Marine Park of Laje de Santos (SMPLS) - São Paulo, Brazil. Braz. J. Oceanogr. 2017, 65, 614-627.

BROECKER W. S. 1974. Chemical Oceanography, New York, Harcourt, Brace, Jovamovich.

CAPERON, J., SCHELL, D., HIROTA, J. \& LAWS, E. 1979. Ammonium excretion rates in Kaneohe Bay, Hawaii, measured by a ${ }^{15} \mathrm{~N}$ isotope dilution technique. Marine Biology, $54,33-40$.

CAUWET, G. 2002. DOM in the Coastal Zone. In: HANSELL, D. A. \& CARLSON, C. A. (eds.) Biogeochemistry of Marine Dissolved Organic Matter. San Diego: Academic Press.

CONAMA - Conselho Nacional do Meio Ambiente. 2001 Resolução Conama n ${ }^{\circ} 295$ de 12 de dezembro de 2001.

CHURCH, M. J., DUCKLOW, H. W. \& KARL, D. M. 2002. Multiyear increases in dissolved organic matter inventories at Station ALHOA in the North Pacific Subtropical Gyre. Limnology and Oceanography, 47, 1-10.

CLARK, L. L., INGALL, E. D. \& BENNER, R. 1998. Marine phosphorus is selectively remineralized. Nature, 393, 426.

COZZI, S., MISTARO, A., SPARNOCCHIA, S., COLUGNATI, L., BAJT, O. \& TONIATTI, L. 2014. Anthropogenic loads and biogeochemical role of urea in the Gulf of Trieste. Science of The Total Environment, 493, 271-281.

DAFNER, E. V, MALLIN, M. A, SOUZA, J. J., WELLS, H. A. \& PARSONS, D. C. 2007. Nitrogen and phosphorus species in the coastal and shelf waters of Southeastern North Carolina, Mid-Atlantic U.S. coast. coast. Marine Chemistry, 103, 289-303.

DEMANCHE, M., CURL, JR., H. \& COUGHENOWER, D. D. 1973. An automated analysis for urea in sea water. Limnology and Oceanography, 18, 686-893.

DUURSMA, E. K. 1961. Dissolved organic carbon, nitrogen and phosphorus in the sea. Neth. J. Sea Res., 1, 1-147

DUURSMA, E. K. 1965. The dissolved organic constituents of seawater. In: J.P. Riley, G. Skirrow (Eds.), Chemical Oceanography, Acad. Press, 433-473. 
EPPLEY, R. W. \& SLOAN, P. R. 1965. Carbon balance experiments with marine pkytoplankton. Journal of the Fisheries Research Board of Canada, 22, 1083-1097.

FLEMING-LEHTINEN, V., RÄIKE, A., KORTELAINEN, P., KAUPPILA, P. \& THOMAS, D. N. 2015. Organic carbon concentration in the northern coastal Baltic Sea between 1975 and 2011. Estuaries and Coasts. 38, 466-481.

FICHOT, C. G., \& BNEER, R. 2014. The fate of terrigenous dissolved organic carbon in a river-influenced ocean margin. Global Biogeochemical Cycles, 28, 300-318.

GLIBERT, P. M. 1982. Regional studies of daily, seasonal and size fraction variability in ammonium remineralization. $\mathrm{Ma}$ rine Biology, 70, 209-222.

GOTO, N., KAWAMURA, T., MITAMURA, O. \& TERAI, H. 1999. Importance of extracellular organic carbon production in the total primary production by tidal-flat diatoms in comparison to phytoplankton. Marine Ecology Progress Series, 190, 289-295.

GRASSHOFF, K., EHRHARDT, M. \& KREMELING, K. 1983. Methods of Seawater Analysis. $2^{\text {nd }}$ ed. Weinhein, Verlag Chemie.

HANSELL, D.A., 2002. DOC in the global ocean carbon cycle. In: Hansell, D.A., Carlson, C.A. (Eds.), Biogeochemistry of Marine Dissolved Organic Matter. Academic Press, San Diego, 685-716.

HANSELL, D.A., C.A. CARLSON 2015. Biogeochemistry of Marine Dissolved Organic Matter, $2^{\text {nd }}$ Edition. Academic Press, 693.

HANSELL, D. A. \& CARLSON, C. A. 1998. Net community production of dissolved organic carbon. Global Biogeochemical Cycles, 12, 443-453.

HARRISON, W. G. 1978. Experimental measurement of nitrogen remineralization in coastal waters. Limnology and Oceanography, 23, 684-694.

HARVEY, H. W. 1955. The chemistry and fertility of the sea waters, London, Cambridge University Press.

HOIKKALA, L., KORTELAINENC, P., SOINNE, H. \& KUOSA, H. 2015. Dissolved organic matter in the Baltic Sea. Journal of Marine Systems, 142, 47-61.

HUNG, J. J., CHEN, C. H., GONG, G. C., SHEU, D. D. \& SHIAH, F. K. 2003. Distributions, stoichiometric patterns and cross-shelf exports of dissolved organic matter in the East China Sea. Deep Sea Research Part II: Topical Studies in Oceanography, 50, 1127-1145.

KOBAYASHI, K., MATSUI, M., HARAGUCHI, H. \& FUWA, K. 1983. Identification of alkaline phosphatase in sea water. Journal of Inorganic Biochemistry, 18, 41-47.

KOLOWITH, L. C., INGALL, E. \& BENNER, R. 2001. Composition and cicling of marine organic phosphorus. Limnology and Oceanography, 46, 309-320.

KRAUSE, H. R., MOCHEL, L. \& STEGMANN, M. 1961. Organishe Sauren als geloste Intermediarprodukte des postmortalen Abbaues von Susswasser - Zoopnalkton. Naturwissenschaften, 48, 434-435.

MAIDA, M. \& B. P. FERREIRA. 1997. Coral reefs of Brazil: an overview. Proceedings $8^{\text {th }}$ International Coral Reef Symposium, Panama, 1, 263-274.

MARKAGER, S., C. A., STEDMON, C. A. \& SØNDERGAARD, M. 2011. Seasonal dynamics and conservative mixing of dissolved organic matter in the temperate eutrophic estuary Horsens Fjord. Estuarine, Coastal and Shelf Science, 92, 376-388.
MENZEL \& VACCARO, 1964 D.W. Menzel, R.F. Vaccaro The measurement of dissolved and particulate organic carbon in sea water. Limnol. and Oceanogr., 9, 138-142

MENZEL, D.W. 1970 The role of in situ decomposition of organic matter on the oncentration of non-conservative properties in the sea. Deep-Sea Res., 17, 751-764

MCCARTHY, J. J. 1972. Uptake of urea by natural population of marine phytoplankton. Limnology and Oceanography, 17, 738-448.

MONAGHAN, E. J. \& RUTTEMBERG, K. C. 1999. Dissolved organic phosphorus in the coastal ocean: reassessment of available methods and seasonal phosphorus profiles from the Eel River shelf. Limnology and Oceanography, 44, 1702-1714.

PARSONS, T. R. \& SEKI, H. 1970. Importance and general implications of organic matter in aquatic environments In: HOOD, D. W. (ed). Simposium Organic matter in natural Waters. Fairbanks: University of Alaska, 1-28.

REDFIELD, A. C., KETCHUM, B. H \& RICHARDS, F. A. 1963. The influence of organisms on the composition of the seawater. In: Hill, M. N. (ed.) The composition of seawater: Comparative and descriptive oceanography. The sea: ideas and observations on progress in the study of the seas, Vol. 2. New York: Interscience Publishers.

RIBAS-RIBAS, M., GÓMEZ-PARRA, A. \& FORJA, J. M. 2011. Spatio-temporal variability of the dissolved organic carbon and nitrogen in a coastal area affected by river input: The nor-

th eastern shelf of the Gulf of Cádiz (SW Iberian Peninsula). Marine Chemistry, 126, 295-308.

RINKER, K. R. \& POWELL, R. T. 2006. Dissolved organic phosphorus in the Mississipi River during spring and fall 2002. Marine Chemistry, 102, 170-179.

RUTTENBERG, K. C. The Global Phosphorus Cycle. 2005. In: SCHLESINGER, W. H. (ed) Biogeochemstry. Treatise of Geochemistry. Vol. 8. $1^{\text {st }}$ ed. New York: Elsevier Science.

SAMBROTTO, R. N., SAVIDGE, G., ROBINSON, C., BOYD, P., TAKAHASHI, T., KARL, D. M., LANGDON, C., CHIPMAN, D., MARRA, J. \& CODISPOTI, L. 1993. Elevated consumption of carbon relative to nitrogen in the surface ocean. Nature, 363, 248-250.

SARAIVA, E. S. B. G. 2002. Nitrogênio e fósforo totais e dissolvidos e sua frações inorgânicas e orgânicas: considerações sobre a metodologia aplicada e estudo de caso em dois sistemas estuarinos do estado de São Paulo. Tese de Livre Docência, Universidade de São Paulo, Instituto Oceanográfico. $133 \mathrm{p}$.

SCHENAU, S. J., REICHART, G. J. \& LANGER, G. J. 2005. Phosphorus burial as a function of paleoproductivity and redox conditions in Arabian Sea sediments. Geochimica et Cosmochimica Acta, 69, 919-931.

SHILOVA, I. N., MILLS, M. M., ROBIDART, J. C., TURK-KUBO, K. A., BJÖRKMAN, K. M., KOLBER, Z., RAPP, I., VAN DIJKEN, G. L., CHURCH, M. J., ARRIGO, K. R., ACHTERBERG, E. P. \& ZEHR, J. P. 2017. Differential effects of nitrate, ammonium, and urea as $\mathrm{N}$ sources for microbial communities in the North Pacific Ocean. Limnology and Oceanography, 62, 2550-2574.

STUERMER D.H., PETERS K.E., KAPLAN I.R. 1978 Source indicators of humic substances and proto-kerogen. Stable isotope ratios, elemental compositions and electron spin resonance spectra Geochim. Cosmochim. Acta, 42, 989-997. 
SUZUMURA, M., ISHIKAWA, K. \& OGAWA, H. 1998. Characterization of dissolved organic phosphorus in coastal seawater using ultrafiltration and phosphohydrolytic enzymes. Limnology and Oceanography, 43, 1553-1564.

THOMSON-BULLDIS, A. \& KARL, D. 1998. Application of a novel method for phosphorus determinations in the oligotrophic North Pacific Ocean. Limnology and Oceanography, 43, 1565-1577.

TRÉGUER, P. \& LE CORRE, P. 1975. Manuel d'analyse des sels nutritifs dans l'eau de mer. Utilisation de l'Autoanalyser II Technicon, 2 ème ed, Université de Bretagne Occidentale, Brest, 110p.

WADA, E. \& HATTORI, A. 1991. Nitrogen in the Sea: Forms, Abundance, and Rate Processes, Boca Raton, CRC Press.
WALSH, J. J., BISCAYE, P. E. \& CSANADY, G. T. 1988. The 1983-1984 shelf edge exchange processes (SEEP) - I experiment: hypotheses and highlights. Continental Shelf Research, $8,435-456$.

WATT, W. D. 1966. Release of dissolved organic material from the cells of phytoplankton populations. Royal Society, 164, 521-551.

WOLLAST, R., 1991. The coastal organic carbon cycle: fluxes, sources, and sinks. In: MANTOURA, R. F. C., MARTIN, J. M. \& WOLLAST, R. (eds.) Ocean Margin Processes in Global Change. Dahlem Workshop Report. Chichester: John Wiley and Sons. 